\title{
The Prognostic Significance of Soluble Urokinase Plasminogen Activator Receptor in Acute Myeloid Leukemia
}

\author{
Akut Miyeloid Lösemili Hastalarda Solubl Ürokinaz Plazminojen Aktivatör Reseptörünün \\ Prognozdaki Önemi
}

Nergiz Erkut1,2, Ahmet Menteşe3,4, Hasan Mücahit Özbaş², Nilay Ermantaş2 ${ }^{2}$ Ayşegül Sümer4, Asım Örem4, Mehmet Sönmez²

${ }^{1}$ Kanuni Training and Research Hospital, Clinic of Hematology, Trabzon, Turkey

2Karadeniz Technical University Faculty of Medicine, Department of Hematology, Trabzon, Turkey

${ }^{3}$ Karadeniz Technical University, Vocational School of Health Sciences, Program of Medical Laboratory Techniques, Trabzon, Turkey

${ }^{4}$ Karadeniz Technical University Faculty of Medicine, Department of Medical Biochemistry, Trabzon, Turkey

\section{Abstract}

Objective: The soluble urokinase plasminogen activator receptor (suPAR) is a soluble form of the urokinase plasminogen activator receptor expressed in various immune and cancer cells. The levels of suPAR have been demonstrated to correlate with prognosis in various cancers. This study was intended to investigate serum suPAR levels and their effect on prognosis in patients with acute myeloid leukemia (AML).

Materials and Methods: Thirty newly diagnosed patients with AML and 29 healthy individuals were enrolled. Serum suPAR levels were analyzed by enzyme-linked immunosorbent assay.

Results: Serum suPAR levels were significantly higher in patients with AML than in healthy individuals $(9 \pm 5.9 \mathrm{ng} / \mathrm{mL}$ and $2.4 \pm 1.4 \mathrm{ng} / \mathrm{mL}$, respectively; $p<0.001)$. Positive correlation was determined between suPAR levels and white blood cell counts $(p<0.01)$. Serum suPAR levels were lower in patients who achieved complete response than in patients not achieving complete response $(5.5 \pm 2.2 \mathrm{ng} / \mathrm{mL}$ and $12 \pm 6.6$ $\mathrm{ng} / \mathrm{mL}$, respectively; $\mathrm{p}<0.001)$. The median overall survival was longer in patients with serum suPAR levels below $6.71 \mathrm{ng} / \mathrm{mL}$ than in those with serum suPAR levels above $6.71 \mathrm{ng} / \mathrm{mL}(12.6 \pm 13.2$ months and $1.71 \pm 0.6$ months, respectively; $p=0.02$ ). Multivariate Cox regression analysis showed that suPAR had independent prognostic value $(95 \%$ confidence interval: 1.029-6.259; $\mathrm{p}<0.05$ ) in AML.

Conclusion: Serum suPAR levels can be used as a prognostic marker in AML.

Keywords: Soluble urokinase plasminogen activator receptor, Acute myeloid leukemia, Prognosis

\begin{abstract}
पे
Amaç: Solubl ürokinaz plazminojen aktivatör reseptörü (süPAR) çeşitli immün sistem ve kanser hücrelerinde eksprese edilen ürokinaz plazminojen aktivatör reseptörün çözünür formudur. Çeşitli kanserlerde süPAR düzeyinin prognoz ile ilişkili olduğu gösterilmiştir. Bu çalışmada akut miyeloid lösemili (AML) hastalarda süPAR düzeyi ve prognoz üzerine olan etkisinin araştırılması planlandı.
\end{abstract}

Gereç ve Yöntemler: Çalışmaya yeni tanı almış 30 AML'li hasta ve 29 sağlıklı birey dahil edildi. Serum süPAR düzeyi enzyme-linked immunosorbent assay yöntemi ile analiz edildi.

Bulgular: Serum süPAR düzeyi AML'li hastalarda sağlıklı bireylere göre önemli derecede daha yüksek tespit edildi $(9 \pm 5,9 \mathrm{ng} / \mathrm{mL}, 2,4 \pm 1,4$ $\mathrm{ng} / \mathrm{mL}$, sırasıyla, $\mathrm{p}<0,001)$. süPAR düzeyi ile lökosit sayısı arasında pozitif bir korelasyon izlendi $(p<0,01)$. Serum süPAR düzeyi, tam remisyona giren hastalarda tam remisyona girmeyen hastalara göre daha düşüktü $(5,5 \pm 2,2 \mathrm{ng} / \mathrm{mL}, 12 \pm 6,6 \mathrm{ng} / \mathrm{mL}$, sırasıyla, $\mathrm{p}<0,001)$. Toplam yaşam süresi, serum süPAR düzeyi $6,71 \mathrm{ng} / \mathrm{mL}$ 'nin altında olan hastalarda, $6,71 \mathrm{ng} / \mathrm{mL}$ üstünde olanlara göre daha uzundu $(12,6 \pm 13,2$ ay, $1,71 \pm 0,6$ ay, sırasıyla, $p=0,02$ ). AML'de çok değişkenli Cox regresyon analizi süPAR düzeyinin bağımsız prognostik değere sahip olduğunu gösterdi (\%95 güven aralığı: 1,029-6,259; $p<0,05)$.

Sonuç: AML'li hastalarda serum süPAR düzeyi prognostik bir belirteç olarak kullanılabilir.

Anahtar Sözcükler: Solubl ürokinaz plazminojen aktivatör reseptörü, Akut miyeloid lösemi, Prognoz
Address for Correspondence/Yazışma Adresi: Nergiz ERKUT, M.D., Kanuni Training and Research Hospital, Clinic of Hematology, Trabzon, Turkey

Phone : +90 4623415656

E-mail : drnusta@hotmail.com
Received/Geliş tarihi: October 10, 2014 Accepted/Kabul tarihi: May 04, 2015 


\section{Introduction}

Acute myeloid leukemia (AML) is a heterogeneous neoplastic disorder characterized by uncontrolled proliferation of hematopoietic stem cells [1]. Although 70\%-80\% of patients younger than 60 years of age achieve complete remission (CR), only 30\%-40\% obtain long-term survival. Moreover, CR is only observed in 10\%-15\% of elderly patients [2]. The pathogenesis of AML involves various disorders, such as mutations in transcription factors or epigenetic modifiers, aberrant signaling pathways, overexpression of the multidrug resistance gene, abnormal immune function, and abnormalities in the bone marrow microenvironment [3]. Prognostic factors include advanced age, poor performance status, high white blood cell (WBC) count, existence of prior myelodysplastic syndrome and myeloproliferative disease, previous history of cytotoxic therapy, and particularly cytogenetics and molecular genetic changes $[4,5]$.

The urokinase plasminogen activator receptor (UPAR) is a glycoprotein consisting of 274 amino acids with a molecular weight of 55-60 kDa attached to the plasma membrane via a glycosylphosphatidylinositol anchor protein [6]. UPAR is expressed in neutrophils, lymphocytes, monocytes, macrophages, fibroblasts, and endothelial and some tumor cells $[7,8,9]$. The soluble urokinase plasminogen activator receptor (suPAR) is a soluble form of uPAR found in serum, plasma, urine, and other body fluids [10]. suPAR affects cancer progression through adhesion, migration, chemotaxis, proteolysis, and invasion [11]. Several studies have demonstrated that suPAR increases in some cancers and is associated with poor prognosis [12]. This study was intended to investigate serum suPAR levels and their effect on prognosis in patients with AML.

\section{Materials and Methods}

Thirty newly diagnosed patients with AML and 29 healthy individuals presenting to the Deparment of Hematology, Faculty of Medicine, Karadeniz Technical University between January 2009 and July 2011 were enrolled in this study. The eligibility criterion was age between 18 and 80 years. Patients with a history of solid cancer or other hematological cancer, the presence of active infection, or active inflammatory disease were excluded. Venous blood specimens collected from both patient and control groups were placed into biochemical separator-containing tubes. Blood samples were centrifuged at $3000 \mathrm{rpm}$ for $10 \mathrm{~min}$ and serum was stored at $-80^{\circ} \mathrm{C}$ for investigation of suPAR levels.

All AML patients were diagnosed according to the World Health Organization classification system [13] and categorized into three groups (i.e. low risk, intermediate risk, and high risk) according to the National Comprehensive Cancer Network guidelines [14].
Patients aged $\leq 60$ years or $61-65$ years with good performance status were treated with the standard regimen [cytarabine, 24-h continuous intravenous (IV) infusion, $100 \mathrm{mg} / \mathrm{m}^{2}$, days 1-7; idarubicin, 30-min IV infusion, $12 \mathrm{mg} / \mathrm{m}^{2}$, days 1-3]. Patients with acute promyelocytic leukemia were treated with all-transretinoic acid (ATRA) plus idarubicin therapy (ATRA, orally, 45 $\mathrm{mg} / \mathrm{m}^{2}$ per day in two divided doses until CR was achieved; idarubicin, 30-min IV infusion, $12 \mathrm{mg} / \mathrm{m}^{2}$, days 2, 4, 6, and 8). Elderly patients were treated with low-dose chemotherapy [low-dose cytarabine, subcutaneous (SC), $10 \mathrm{mg} / \mathrm{m}^{2}$, twice a day, days 1-10; or 5-azacytidine, SC, $75 \mathrm{mg} / \mathrm{m}^{2}$, days 1-7]. Remission status was evaluated after the completion of cancer therapy according to conventional criteria. Patients were followed for 2 years, monthly for the first year and every third month in the following year.

\section{Measurement of Soluble Urokinase Plasminogen Activator Receptor Levels}

The levels of serum suPAR were determined by enzyme-linked immunosorbent assay kit (ViroGates A/S, Denmark) according to the manufacturer's protocols. The absorbance of samples was measured at $450 \mathrm{~nm}$ using a VERSA max tunable microplate reader (designed by Molecular Devices, USA). The results were expressed as $\mathrm{ng} / \mathrm{mL}$. The minimum detection limit of the assay was estimated to be $0.1 \mathrm{ng} / \mathrm{mL}$.

\section{Statistical Analysis}

All analyses were carried out using SPSS 21.0. Descriptive statistical analysis was performed for all studied variables. Data were tested for normal distribution using the KolmogorovSmirnov test. Statistical comparisons between the patient and control groups were carried out using the Mann-Whitney test and chi-square test. The associations between serum suPAR levels and hemoglobin $(\mathrm{Hb})$ or hematocrit levels and white blood cell (WBC) or platelet count were examined by Spearman correlation analysis. The area under the receiver operating characteristic (ROC) curve was used to compare the discriminative power of suPAR levels in the diagnosis of AML. Estimates of overall survival (OS) were calculated using the Kaplan-Meier method. The logrank test was used to analyze the effect on survival time of each variable. The Cox regression model was applied for multivariate analysis. Linear regression analysis was used to investigate the relationship between serum suPAR levels and sex, patient age, WBC count, French-American-British (FAB) classification, and Fms-like tyrosine receptor kinase-3 (FLT-3) mutation. A value of $\mathrm{p}<0.05$ was considered statistically significant.

\section{Results}

Thirty patients with AML and 29 healthy controls were included in the study. There were no statistical differences in term of age or sex between the two groups. Risk groups included 6 
patients at good risk, 19 at intermediate risk, and 5 at poor risk. At the end of the 2-year follow-up, 26 patients had died and 4 survived. Fourteen patients exhibited CR after remissioninduction chemotherapy, while CR was not achieved in the other 16. Table 1 shows the general characteristics and laboratory findings for both patients and healthy individuals.

Serum suPAR levels were significantly higher in patients with AML than in healthy individuals $(9 \pm 5.9 \mathrm{ng} / \mathrm{mL}$ and $2.4 \pm 1.4 \mathrm{ng} /$ $m L$, respectively; $p<0.001$ ) (Figure 1). Positive correlation was determined between suPAR levels and WBC count in patients with $A M L(p<0.01)$ (Figure 2), whereas there was no correlation between suPAR levels and Hb levels or platelet count. There was no significant difference in serum suPAR levels between patients aged $\leq 60$ and $>60$ years $(7.6 \pm 4.4 \mathrm{ng} / \mathrm{mL}$ and $12.3 \pm 8 \mathrm{ng} / \mathrm{mL}$, respectively; $p>0.05)$. Serum suPAR levels were lower in patients who achieved $C R$ than in patients not achieving CR $(5.5 \pm 2.2 \mathrm{ng} /$ $\mathrm{mL}$ and $12 \pm 6.6 \mathrm{ng} / \mathrm{mL}$, respectively; $\mathrm{p}<0.001$ ) (Figure 3 ).

In AML patients, the area under the ROC curve for suPAR was 0.938 [95\% confidence interval (CI): 0.843-0.984]. For the optimum diagnostic cut-off value of $2.79 \mathrm{ng} / \mathrm{mL}$, the sensitivity and specificity were $96.67 \%$ and $79.31 \%$, respectively (Figure 4).

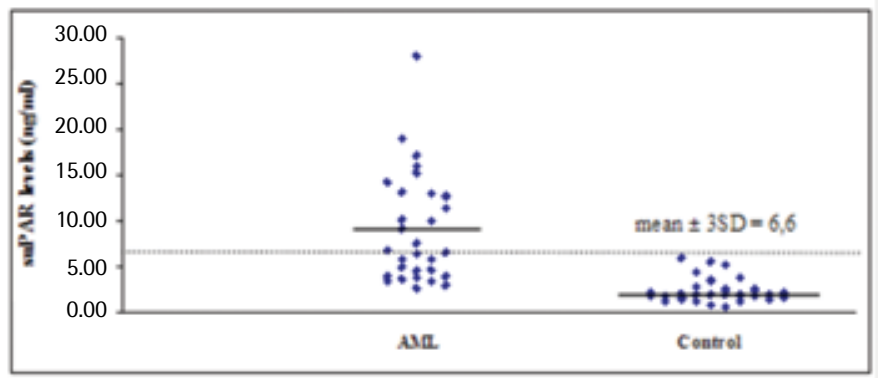

Figure 1. Soluble urokinase plasminogen activator receptor concentrations in serum from acute myeloid leukemia patients and healthy controls. The dotted line indicates the mean value plus 3 standard deviations of healthy control serum $(6.6 \mathrm{ng} / \mathrm{mL})$. suPAR: Soluble urokinase plasminogen activator receptor, AML: acute myeloid leukemia, SD: standard deviation.

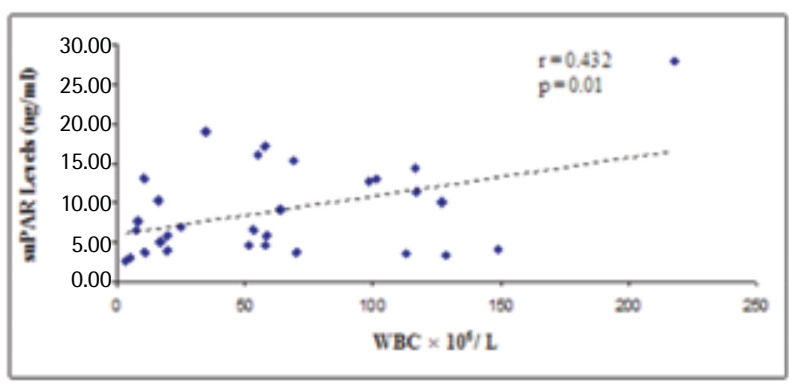

Figure 2. Correlations between soluble urokinase plasminogen activator receptor levels and white blood cell count in acute myeloid leukemia patients. WBC: White blood cell, suPAR: soluble urokinase plasminogen activator receptor, AML: acute myeloid leukemia.
The median OS of AML patients was 4.16 months (range: 0-32.9 months). In the Kaplan-Meier analysis and the Cox regression model, patients with high serum suPAR levels showed a trend toward poorer survival $(p=0.02)$. The median OS was longer in patients with serum suPAR levels below $6.71 \mathrm{ng} / \mathrm{mL}$ than in those with serum suPAR levels above $6.71 \mathrm{ng} / \mathrm{mL}(12.6 \pm 13.2$ months and $1.71 \pm 0.6$ months, respectively; $p=0.02$ ) (Figure 5). WBC count had no significant effect on OS $(p=0.9)$ (Figure 6). In linear regression analysis, sex, patient age, WBC count, FAB classification (i.e. M2, M3, M4, M5), and FLT-3 mutation were not associated with serum suPAR levels ( $p>0.05)$. Multivariate Cox regression analysis showed that suPAR had independent prognostic value $(95 \% \mathrm{Cl}: 1.029-6.259 ; \mathrm{p}<0.05)$ in AML. When the suPAR cut-off level was considered as $6.71 \mathrm{ng} / \mathrm{mL}$, mortality risk was 2.5-fold higher in patients with levels above the cut-off limit.

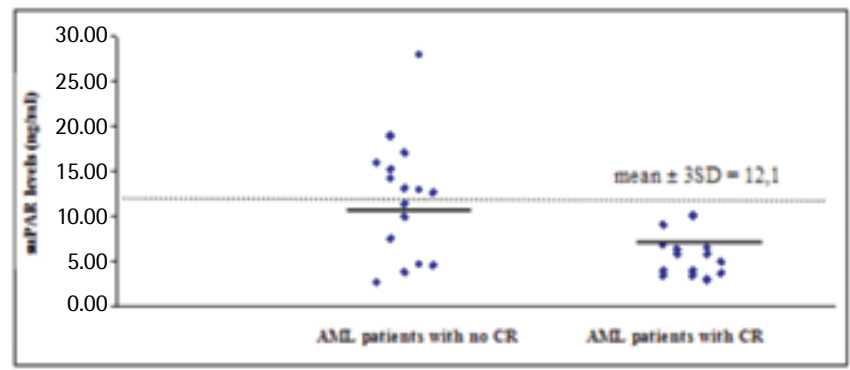

Figure 3. Soluble urokinase plasminogen activator receptor concentrations in serum from acute myeloid leukemia patients with no complete remission and acute myeloid leukemia patients with complete remission. The dotted line indicates the mean value plus 3 standard deviations of serum of acute myeloid leukemia patients with complete remission $(12.1 \mathrm{ng} / \mathrm{mL})$. suPAR: Soluble urokinase plasminogen activator receptor, AML: acute myeloid leukemia, SD: standard deviation, CR: complete remission.

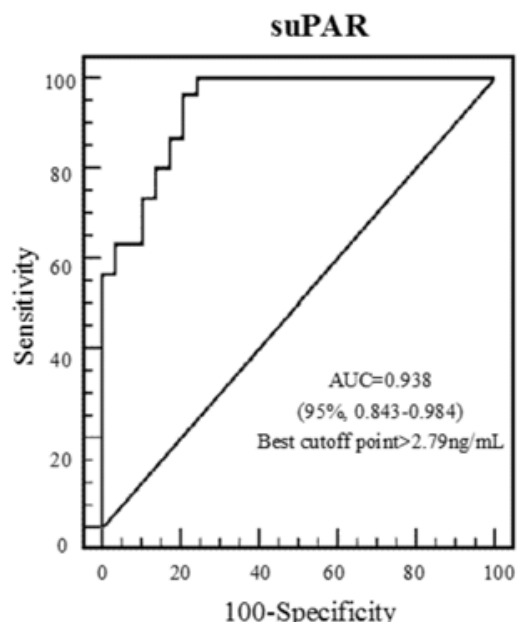

Figure 4. The receiver operating characteristic curves of acute myeloid leukemia patients according to soluble urokinase plasminogen activator receptor levels. suPAR: Soluble urokinase plasminogen activator receptor, AUC: area under the curve. 


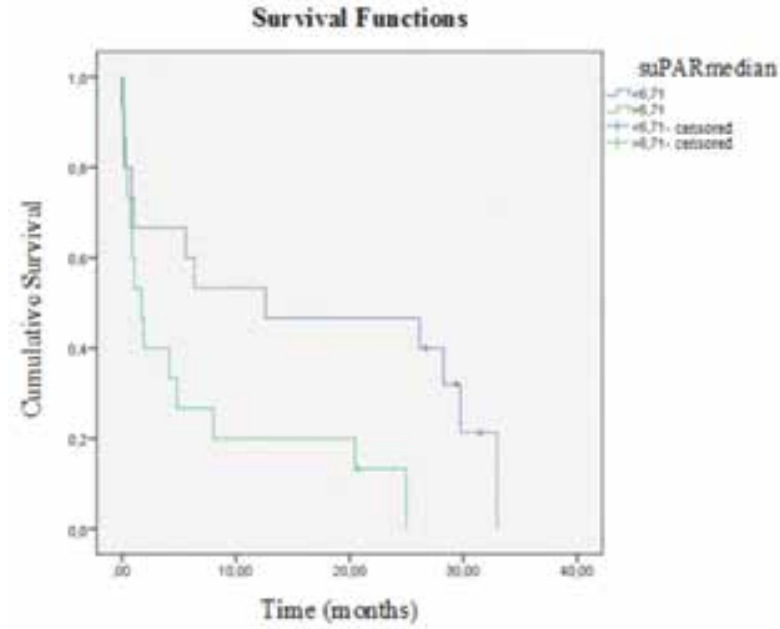

Figure 5. Kaplan-Meier curves of acute myeloid leukemia patients according to soluble urokinase plasminogen activator receptor levels. suPAR: Soluble urokinase plasminogen activator receptor.

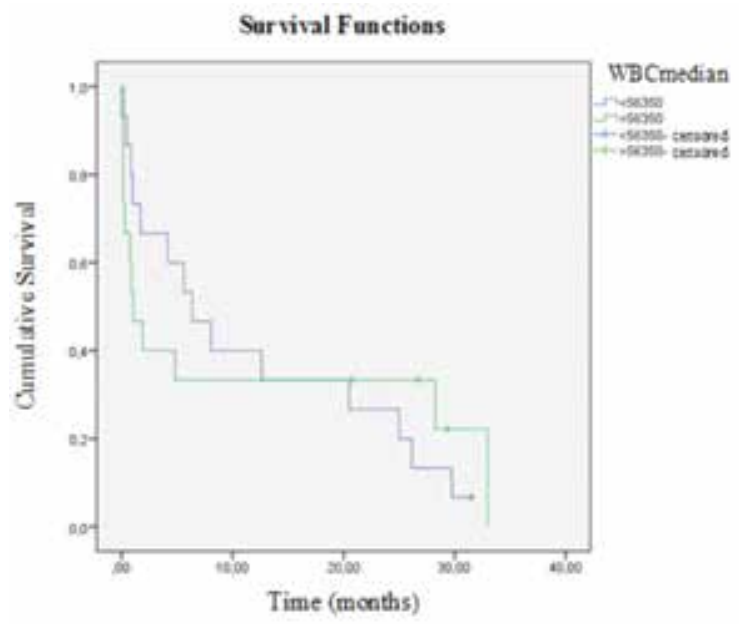

Figure 6. Kaplan-Meier curves of acute myeloid leukemia patients according to white blood cell count. WBC: White blood cell.

\section{Discussion}

The urokinase-mediated plasminogen activation (UPA) system plays an important role in tissue remodeling, angiogenesis, proteolysis, migration, chemotaxis, invasion, and metastasis $[15,16,17]$. The UPA system consists of UPA, UPAR, plasminogen, and plasminogen activator inhibitor [18]. In vitro studies have shown that suPAR is associated with cell adhesion, migration, and proliferation $[19,20]$. Elevated suPAR levels have been determined in solid cancers such as ovarian [21], endometrial, cervical [22], breast [23], stomach [24], colon [25], and non-small cell lung cancer [26]. Positive associations between serum suPAR levels and soluble serum CD138, creatinine, $\beta 2$ microglobulin, stage of disease, and extramedullary bone marrow involvement have been reported in patients with multiple myeloma [27].

In acute leukemia, circulating blast cells provide an important advantage for studying proteins expressed on the tumor
Table 1. Characteristics of acute myeloid leukemia patients.

\begin{tabular}{|c|c|}
\hline Parameters & $n=30$ \\
\hline Median age (minimum-maximum), years & $52(24-80)$ \\
\hline$\leq 60$ years, $\mathrm{n}(\%)$ & $22(73.3)$ \\
\hline$>60$ years, $\mathrm{n}(\%)$ & $8(26.7)$ \\
\hline \multicolumn{2}{|l|}{ Sex, n (\%) } \\
\hline Female & $17(56.7)$ \\
\hline Male & $13(43.3)$ \\
\hline \multicolumn{2}{|l|}{ Risk groups, n (\%) } \\
\hline Good risk & $6(20)$ \\
\hline Intermediate risk & $19(63.3)$ \\
\hline Poor risk & $5(16.7)$ \\
\hline \multicolumn{2}{|l|}{ Classification of $A M L, n(\%)$} \\
\hline AML with recurrent genetic abnormalities & $7(23.3)$ \\
\hline $\mathrm{t}(15 ; 17)(q 22 ; q 12) ; \mathrm{PML}-\mathrm{RARA}$ & $3(10)$ \\
\hline $\mathrm{t}(8 ; 21)(q 22 ; q 22) ;$ RUNX1-RUNX1T1 & $2(6.7)$ \\
\hline $\mathrm{t}(16 ; 16)(\mathrm{p} 13.1 \mathrm{q} 22) ; \mathrm{CBFB}-\mathrm{MYH} 11$ & $1(3.3)$ \\
\hline $\operatorname{lnv}(3)(q 21 q 26.2) ;$ RPN1-EVI1 & $1(3.3)$ \\
\hline AML with MDS-related changes & $5(16.7)$ \\
\hline AML, therapy-related & $1(3.3)$ \\
\hline AML not otherwise categorized & $16(53.2)$ \\
\hline AML minimally differentiated & $1(3.3)$ \\
\hline AML without maturation & $1(3.3)$ \\
\hline AML with maturation & $7(23.3)$ \\
\hline Acute myelomonocytic leukemia & $6(20)$ \\
\hline Acute monocytic leukemia & $1(3.3)$ \\
\hline Other & $1(3.3)$ \\
\hline \multicolumn{2}{|c|}{ Laboratory findings at baseline, median (minimum-maximum) } \\
\hline WBC count $\left(\times 10^{9} / \mathrm{L}\right)$ & $62(3.6-218)$ \\
\hline $\mathrm{Hb}(\mathrm{g} / \mathrm{dL})$ & $9.9(5-17.5)$ \\
\hline Platelets (x109/L) & $64(9-198)$ \\
\hline FLT-3 mutation, $\mathrm{n}(\%)$ & $6(20)$ \\
\hline \multicolumn{2}{|l|}{ Treatment regimen, $\mathrm{n}(\%)$} \\
\hline Cytarabine plus idarubicin (10 CR, 11 without CR) & $21(70)$ \\
\hline ATRA plus idarubicin (3 CR) & $3(10)$ \\
\hline 5-azacitidine (1 CR, 4 without $C R)$ & $5(16.7)$ \\
\hline Low-dose cytarabine (1 without CR) & $1(3.3)$ \\
\hline \multicolumn{2}{|l|}{ Remission-induction chemotherapy response, $\mathrm{n}(\%)$} \\
\hline $\mathrm{CR}$ & $14(46.7)$ \\
\hline No CR & $16(53.3)$ \\
\hline
\end{tabular}


cell surface. Lanza et al. demonstrated that uPAR (CD87) expression increased in patients with $A M L$ and was associated with mucocutaneous infiltration, hepatosplenomegaly, lymphadenopathy, and central nervous system involvement [28]. The levels of suPAR in the plasma of mice during the growth of xenografted cell lines were significantly related to tumor volume [29]. Mustjoki et al. reported that increased suPAR levels were correlated with number of circulating tumor cells in AML and that serum suPAR levels decreased rapidly after cytotoxic treatment [30]. Aref et al. further demonstrated that serum suPAR levels were significantly higher in AML patients as compared to controls [31]. Similarly, in our study, serum suPAR levels significantly increased in patients with AML compared to healthy individuals. In addition, suPAR was observed to possess high sensitivity and specificity in patients with AML in ROC analysis. There was a positive correlation between suPAR levels and number of circulating WBCs. Therefore, we think that the production of suPAR is related to blast cells in the peripheral circulation.

Lomholt et al. demonstrated that elevated suPAR levels were independent prognostic factors in patients with colorectal cancer [32]. Another study showed that high suPAR levels were associated with poor outcome in patients with breast cancer independent of tumor size, estrogen receptor status, and lymph node status [23]. On the other hand, Begum et al. reported that preoperative plasma suPAR levels were not correlated with prognosis for stage III ovarian cancer patients [33]. In our study, serum suPAR levels were significantly higher in patients who did not achieve CR than in patients achieving CR. More importantly, high suPAR levels were associated with poor prognosis in patients with AML. When the suPAR cut-off level was considered as $6.71 \mathrm{ng} / \mathrm{mL}$, mortality risk was 2.5 -fold higher in patients with levels above the cut-off limit. Sex, patient age, WBC count, FAB classification (i.e. M2, M3, M4, M5) and FLT-3 mutation were not associated with serum suPAR levels ( $p>0.05$ ). Serum suPAR levels were an independent prognostic indicator for the OS of patients with AML.

\section{Conclusion}

In conclusion, our study indicates that suPAR increases in patients with AML and this situation is associated with poorer survival. suPAR can thus be used as a diagnostic and prognostic biomarker in AML and may help in the developing of specific therapeutic targets. However, further studies are required to assess the clinical relevance of suPAR.

\section{Ethics}

Ethics Committee Approval: The study was approved by the Local Ethics Committee of the Karadeniz Technical University Faculty of Medicine, and was conducted in accordance with the Declaration of Helsinki. Informed consent was taken from all patients and healthy subjects.

\section{Authorship Contributions}

Concept: Nergiz Erkut, Mehmet Sönmez; Design: Nergiz Erkut, Mehmet Sönmez; Data Collection or Processing: Nergiz Erkut, Ahmet Menteşe, Hasan Mücahit Özbaş, Nilay Ermantaş, Ayşegül Sümer, Asım Örem, Mehmet Sönmez; Analysis or Interpretation: Nergiz Erkut, Ahmet Menteşe; Literature Search: Nergiz Erkut, Ahmet Menteşe, Hasan Mücahit Özbaş, Nilay Ermantaş, Ayşegül Sümer, Asım Örem, Mehmet Sönmez; Writing: Nergiz Erkut, Ahmet Menteşe, Hasan Mücahit Özbaş, Nilay Ermantaş, Ayşegül Sümer, Asım Örem, Mehmet Sönmez.

Conflict of Interest: The authors of this paper have no conflicts of interest, including specific financial interests, relationships, and/or affiliations relevant to the subject matter or materials included.

\section{References}

1. Andreeff M, Quintas-Cardama A. Pathobiology of acute myeloid leukemia. In: Hoffman R, Benz EJ, Silberstein LE (eds). Hematology Basic Principles and Practice. 6th ed. Philadelphia, Elsevier Saunders, 2013.

2. Ungewickell A, Medeiros BC. Novel agents in acute myeloid leukemia. Int J Hematol 2012;96:178-185.

3. Roboz GJ. Current treatment of acute myeloid leukemia. Curr Opin Oncol 2012;24:711-719.

4. Burnett $A$, Wetzler M, Löwenberg B. Therapeutic advances in acute myeloid leukemia. J Clin Oncol 2011;29:487-494.

5. Döhner H, Estey EH, Amadori $S$, Appelbaum FR, Büchner T, Burnett AK Dombret $H$, Fenaux P, Grimwade D, Larson RA, Lo-Coco F, Naoe T, Niederwieser D, Ossenkoppele GJ, Sanz MA, Sierra J, Tallman MS, Löwenberg B, Bloomfield CD; European LeukemiaNet. Diagnosis and management of acute myeloid leukemia in adults. recommendations from an international expert panel, on behalf of the European LeukemiaNet. Blood 2010;115:453-474.

6. Nielsen LS, Kellerman GM, Behrendt N, Picone R, Danø K, Blasi F. A 55,000$60,000 \mathrm{Mr}$ receptor protein for urokinase-type plasminogen activator. Identification in human tumor cell lines and partial purification. J Biol Chem 1988;263:2358-2363.

7. Nykjaer A, Moller B, Todd RF, Christensen T, Andreasen PA, Gliemann J, Petersen CM. Urokinase receptor. An activation antigen in human $\mathrm{T}$ lymphocytes. J Immunol 1994;152:505-516.

8. Gyetko MR. The urokinase receptor is required for human monocyte chemotaxis in vitro. J Clin Invest 1994;93:1380-1387.

9. Chavakis T, Willuweit AK, Lupu F, Preissner KT, Kanse SM. Release of soluble urokinase receptor from vascular cells. Thromb Haemost 2001;86:686-693.

10. Ploug M, Ronne $E$, Behrendt N, Jensen AL, Blasi F, Danø K. Cellular receptor for urokinase plasminogen activator. Carboxyl-terminal processing and membrane anchoring by glycosyl-phosphatidylinositol. J Biol Chem 1991;266:1926-1933.

11. Donadello $K$, Scolletta $S$, Covajes $C$, Vincent JL. suPAR as a marker of disease severity and risk of mortality in sepsis. BMC Med 2012;10:2.

12. Dano K, Behrendt N, Hoyer-Hansen G, Johnsen M, Lund LR, Ploug M, Rømer J. Plasminogen activation and cancer. Thromb Haemost 2005;93:676-681.

13. Liesveld JL, Lichtman MA. Acute myelogenous leukemia. In: Kaushansky K, Lichtman MA, Beutler E, Kipps TJ, Seligsohn U, Prchal JT (eds). Williams Hematology. 8th ed. New York, McGraw-Hill, 2010.

14. O'Donnell MR, Tallman MS, Abboud CN, Altman JK, Appelbaum FR, Arber DA, Attar E, Borate U, Coutre SE, Damon LE, Lancet J, Maness U, Marcucci G, Martin MG, Millenson MM, Moore JO, Ravandi F, Shami PJ, Smith BD, Stone RM, Strickland SA, Wang ES, Gregory KM, Naganuma M. National Comprehensive Cancer Network. Acute myeloid leukemia. Version 2.2013. J Natl Compr Netw 2013;11:1047-1055. 
15. Pöllanen J, Stephens RW, Vaheri A. Directed plasminogen activation at the surface of normal and malignant cells. Adv Cancer Res 1991;57:273-328.

16. Andreasen $\mathrm{PA}$, Egelund $\mathrm{R}$, Petersen $\mathrm{HH}$. The plasminogen activation system in tumor growth, invasion, and metastasis. Cell Mol Life Sci 2000;57:25-40.

17. Castellino FJ, Ploplis VA. Structure and function of the plasminogen/plasmin system. Thromb Haemost 2005;93:647-654.

18. de Bock CE, Wang Y. Clinical significance of urokinase-type plasminogen activator receptor (UPAR) expression in cancer. Med Res Rev 2004;24:13-39.

19. Wilhelm OG, Wilhelm S, Escott GM, Lutz V, Magdolen V, Schmitt M, Rifkin DB, Wilson EL, Graeff H, Brunner G. Cellular glycosylphosphatidylinositolspecific phospholipase D regulates urokinase receptor shedding and cell surface expression. J Cell Physiol 1999;180:225-235.

20. Mizukami IF, Todd RF 3rd. A soluble form of the urokinase plasminogen activator receptor (suPAR) can bind to hematopoietic cells. J Leulocyte Biol 1998;64:203-213.

21. Wahlberg K, Høyer-Hansen G, Casslen B. Soluble receptor for urokinase plasminogen activator in both full-length and a cleaved form is present in high concentration in cystic fluid from ovarian cancer. Cancer Res 1998;58:3294-3298.

22. Riisbro R, Stephens RW, Brünner N, Christensen IJ, Nielsen HJ, Heilmann L, von Tempelhoff GF. Soluble urokinase plasminogen activator receptor in preoperatively obtained plasma from patients with gynecological cancer or benign gynecological diseases. Gynecol Oncol 2001;82:523-531.

23. Riisbro R, Christensen IJ, Piironen T, Greenall M, Larsen $B$, Stephens RW, Han C, Høyer-Hansen G, Smith K, Brünner N, Harris AL. Prognostic significance of soluble urokinase plasminogen activator receptor in serum and cytosol of tumor tissue from patients with primary breast cancer. Clin Cancer Res 2002;8:1132-1141.

24. Fidan E, Mentese A, Ozdemir F, Deger O, Kavgaci H, Karahan SC, Aydin F. Diagnostic and prognostic significance of CA IX and suPAR in gastric cancer. Med Oncol 2013;30:540.

25. Stephens RW, Nielsen HJ, Christensen IJ, Thorlacius-Ussing O, Sørensen S, Danø K, Brünner N. Plasma urokinase receptor levels in patients with colorectal cancer: relationship to prognosis. J Natl Cancer Inst 1999;91:869-874.

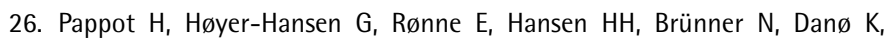
Grøndahl-Hansen J. Elevated plasma levels of urokinase plasminogen activator receptor in non-small cell lung cancer patients. Eur J Cancer 1997;33:867-872.

27. Rigolin GM, Tieghi A, Ciccone M, Bragotti LZ, Cavazzini F, Della Porta M, Castagnari B, Carroccia R, Guerra G, Cuneo A, Castoldi G. Soluble urokinasetype plasminogen activator receptor (suPAR) as an independent factor predicting worse prognosis and extra-bone marrow involvement in multiple myeloma patients. Br J Haematol 2003;120:953-959.

28. Lanza F, Castoldi GL, Castagnari B, Todd RF 3rd, Moretti S, Spisani S, Latorraca A, Focarile E, Roberti MG, Traniello $S$. Expression and functional role of urokinase-type plasminogen activator receptor in normal and acute leukemic cells. Br J Haematol 1998;103:110-123.

29. Holst-Hansen C, Hamers MJ, Johannessen BE, Brünner N, Stephens RW. Soluble urokinase receptor released from human carcinoma cells: a plasma parameter for xenograft tumour studies. Br J Cancer 1999;81:203-211.

30. Mustjoki S, Sidenius N, Sier CFM, Blasi F, Elonen E, Alitalo R, Vaheri A. Soluble urokinase receptor levels correlate with number of circulating tumor cells in acute myeloid leukemia and decrease rapidly during chemotherapy. Cancer Research 2000;60:7126-7132.

31. Aref S, El-Sherbiny M, Mabed M, Menessy A, El-Refaei M. Urokinase plasminogen activator receptor and soluble matrix metalloproteinase- 9 in acute myeloid leukemia patients: a possible relation to disease invasion. Hematology 2003;8:385-391.

32. Lomholt AF, Christensen IJ, Høyer-Hansen G, Nielsen HJ. Prognostic value of intact and cleaved forms of the urokinase plasminogen activator receptor in a retrospective study of 518 colorectal cancer patients. Acta Oncol 2010;49:805-811.

33. Begum FD, Høgdall CK, Kjaer SK, Christensen L, Blaakaer J, Bock JE, Glud E, Høyer-Hansen $G$, Ring-Larsen $H, H ø g d a l l ~ E V$. The prognostic value of plasma soluble urokinase plasminogen activator receptor (suPAR) levels in stage III ovarian cancer patients. Anticancer Res 2004;24:1981-1986. 